\author{
Mariusz Kudełko*, Małgorzata Wejer**
}

\title{
Selected implications of negative externalities - on the example of the Polish energy sector
}

\section{Introduction}

The conditions of a competitive market are very restrictive and, as such on many markets, are not met. The term "market failure" refers to any situation where the balance set on free and non-regulated markets (i.e., markets without direct control of the government in the cases of price or quantity) does not lead to the effective allocation of resources. Unpredictability (i.e., market failure) stands for all situations in which interference prevents the 'invisible hand' from efficient allocation. The examples of these failures are: imperfect competition, economic instability, lack of complete information, the existence of public goods, and externalities. The energy market is a typical example of market failure in terms of negative externalities associated with negative effects on the environment.

This paper consists of two parts - theoretical and empirical. In the first part, the authors place a strong emphasis on the economic consequences of market failure with respect to externalities - both positive and negative. Moreover, positive and negative externalities as well as the decision criteria used in costbenefit analysis (a method supporting a decision-making process) have been profoundly characterized from a theoretical perspective. In the second part, the authors' describe the mathematical model used for forecasting the long-term development of the domestic energy sector. An example reflecting the inefficiency caused by the negative effects produced by the Polish energy sector as well as the lack of so-called internalization of external costs have been shown. It should be emphasized that the importance of the results are that, unlike other works, they demonstrate the development of the sector from a social perspective. It is indicated that the type of decision-making criterion is essential to the nature and

\footnotetext{
* AGH University of Science and Technology, Faculty of Management, e-mail: mkudelko@zarz.agh.edu.pl.
}

** University of Applied Sciences, Bremerhaven, Germany, e-mail: malgo.wejer@gmail.com. 
scope of economic results. It has proven that the results (in aggregated form of discounted welfare) may differ significantly from the traditional approach, based on the minimization of private costs.

\section{Positive and negative external effects}

The concept of external effect first appeared in the work of Marshall in 1890 (Marshall 1890). However, the most substantial contribution to research on external effects was introduced by Pigou in The Economics of Welfare (Pigou 1932). Based on the theory of welfare, he distinguished the concept of private and social benefits as well as private and social costs. He defined externalities as the divergences between private and social benefits or costs. In turn, Stiglitz believes that the external effect occurs when a person or company takes action that has an impact on the situation of other people or companies (who are not compensated by corresponding payments).

There are two factors in the literature that characterize the external effects. The first is the impact of one entity on another in such a way that it changes the utility or production functions of the entity that does not participate in the activity that caused the change. The second factor is the lack of penalties imposed on the entity that causes the external effects. Following this literature, the negative external effect arises when the decision made by an individual (in terms of production or consumption) has a direct and negative impact on other people's production or consumption. In other words, it is a situation in which the welfare of one entity (a private person or company) is reduced by another entity just due to its existence. In practice, this means a situation in which companies produce goods at a reduced price that does not include the total social costs of its production.

The distinction between the concepts of externality and external cost is necessary and justified by the measurability of effects that arise as a result of business activities. The external effect takes place in the case of both measurable and unmeasurable effects, while external cost is related only to measurable effects that may be internalized and consequently included in the production costs. Some economists believe that, instead of the concept of external cost, the term of social cost should be applied (Kapp 1961). According to this approach, social costs are those that are borne by another entity than the one that caused them.

Figure 1 and Table 1 present the economic consequences of such a situation for a competitive market. If there are negative externalities, marginal social cost (MSC) is higher than the private cost of production (MPC) at about the size of external costs (MEC). If companies do not include external costs in their cost 
Selected implications of negative externalities...

calculations, the market supply function includes only private costs (MPC). Market equilibrium is achieved at the price of $P_{1}$ and the production volume of $Q_{1}$. However, if a company paid for the negative effects, the equilibrium point would be different $-\mathrm{P}^{*}$ and $\mathrm{Q}^{*}$. Consequently, the existence of negative externalities causes an overproduction of $\mathrm{Q}_{1}-\mathrm{Q}^{*}$.

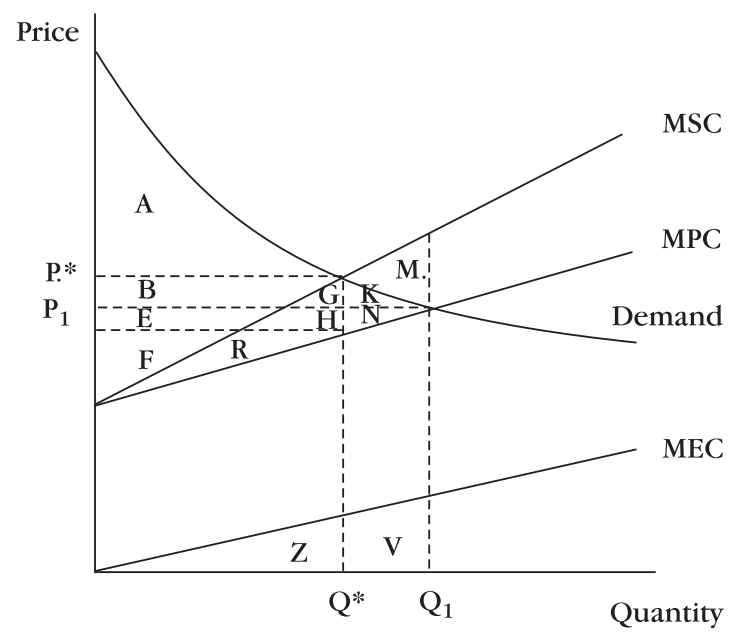

Figure 1. Negative externalities

Table 1

Negative externalities - economic consequences

\begin{tabular}{|l|c|c|c|}
\hline \multicolumn{1}{|c|}{ Characteristics } & $\begin{array}{c}\text { Market } \\
\text { equilibrium }\end{array}$ & Social optimum & $\begin{array}{c}\text { The difference } \\
\text { between social } \\
\text { optimum and } \\
\text { market equilibrium }\end{array}$ \\
\hline Consumers surplus & $\mathrm{A}+\mathrm{B}+\mathrm{G}+\mathrm{K}$ & $\mathrm{A}$ & $-\mathrm{B}-\mathrm{G}-\mathrm{K}$ \\
\hline Producers surplus & $\begin{array}{c}\mathrm{E}+\mathrm{F}+\mathrm{R}+\mathrm{H} \\
+\mathrm{N}\end{array}$ & $\begin{array}{c}\mathrm{B}+\mathrm{E}+\mathrm{F}+\mathrm{R}+ \\
\mathrm{H}+\mathrm{G}\end{array}$ & $\mathrm{B}+\mathrm{G}-\mathrm{N}$ \\
\hline External cost & $\begin{array}{c}\mathrm{R}+\mathrm{H}+\mathrm{N}+\mathrm{G}+ \\
\mathrm{K}+\mathrm{M}\end{array}$ & $\mathrm{R}+\mathrm{H}+\mathrm{G}$ & $\mathrm{M}+\mathrm{N}+\mathrm{K}$ \\
\hline Net social welfare & $\begin{array}{c}\mathrm{A}+\mathrm{B}+\mathrm{E}+\mathrm{F} \\
-\mathrm{M}\end{array}$ & $\mathrm{A}+\mathrm{B}+\mathrm{E}+\mathrm{F}$ & $\mathrm{M}$ \\
\hline Social loss & $\mathrm{M}$ & zero & $\mathrm{M}$ \\
\hline
\end{tabular}


The economic consequences for producers (producer surplus), consumer (consumer surplus), and the environment (external costs) of both situations are presented in Table 1. Net social welfare is the sum of consumer and producer surpluses minus external costs. If the volume of production is $\mathrm{Q}^{*}$, and the product is sold at a market price $\mathrm{P}^{*}$, net social welfare would increase by field $\mathrm{M}$. Of course, it creates serious distribution effects. Consumers would suffer losses in the sum of fields B, G, K, whereas the situation of producers would improve by the total of fields $B+G-N$. Environmental costs would decrease by the sum of fields $\mathrm{M}+\mathrm{N}+\mathrm{K}$.

In the case of positive externalities, marginal social benefits of the supply of a goods exceed marginal private benefits. This means that, in this case, a company produces too little as a result of not considering external benefits. Naturally, when a consumer purchases a product, only individual benefits are considered regardless of the benefits to others. Good examples of positive externalities are education, health, and research.

Figure 2 and Table 2 present the economic consequences of the positive externalities. Market demand is represented by curve MPB. It is the sum of the individual benefits enjoyed by consumers who purchase a particular good. The supply curve represents MPC producers who deliver a good at different marginal costs.

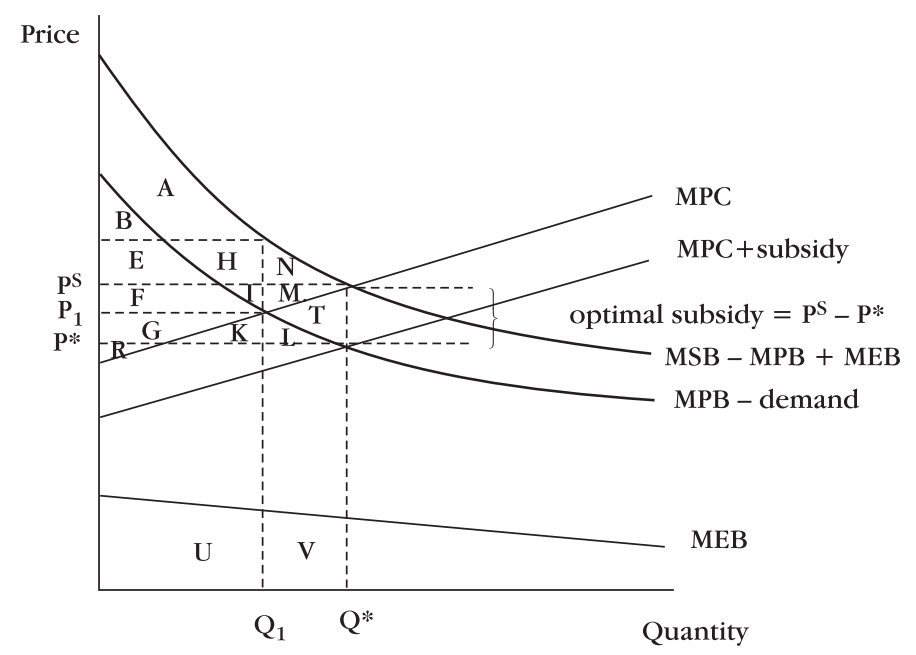

Figure 2. Positive externalities

The market is in equilibrium at the price of $P_{1}$ and the volume of production of $Q_{1}$. In this situation, a consumer surplus is the area below the demand curve 
MBP and above the price of $\mathrm{P}_{1}$ and equals $\mathrm{PS}=\mathrm{B}+\mathrm{E}+\mathrm{F}$. However, there are positive externalities associated with goods consumption that corresponds to the MEB curve. Thus, the marginal social benefit exceeds the marginal private benefit: MSB $=$ MPB + MEB. Consequently, in the market equilibrium at the price of $P_{1}$ and the volume of production of $Q_{1}$, the amount of the external benefit equals:

$$
\mathrm{EB}=\mathrm{A}+\mathrm{H}+\mathrm{J}
$$

At the equilibrium point, social benefits are the sum of private benefits for consumers (consumer surplus), producer surplus, and positive externalities:

$$
\mathrm{NSP}=\mathrm{A}+\mathrm{B}+\mathrm{E}+\mathrm{F}+\mathrm{G}+\mathrm{H}+\mathrm{J}+\mathrm{R}
$$

However, from a social perspective, it is not the optimal level of production. In this point, the marginal cost of producing the last unit of a good is $\mathrm{P}_{1}$ that is lower than the marginal social benefit derived from the production of this good. Therefore, from a social point of view, it is profitable to increase the production to the level of $Q^{*}$, where marginal social benefit equals the marginal cost of producing the last unit of a good. At this level of production, the social welfare may be improved by $\mathrm{M}+\mathrm{N}$. In order to provide a socially-optimal production level, it is necessary to introduce subsidies for producers (which are similar to a negative tax) in the amount of $\mathrm{P}^{\mathrm{s}}-\mathrm{P} *$ (which will motivate producers to deliver optimum output). The economic consequences for producers, consumers, the government (in the case of intervention), and individuals who achieve positive externalities are presented in the Table 2 .

Table 2

Positive externalities - economic consequences

\begin{tabular}{|l|c|c|c|}
\hline \multicolumn{1}{|c|}{ Characteristics } & $\begin{array}{c}\text { Market } \\
\text { equilibrium } \\
\text { (without } \\
\text { subsidy) }\end{array}$ & $\begin{array}{c}\text { Social optimum } \\
\text { (subsidy) }\end{array}$ & $\begin{array}{c}\text { The difference } \\
\text { between social } \\
\text { optimum and market } \\
\text { equilibrium }\end{array}$ \\
\hline Consumers surplus & $\mathrm{B}+\mathrm{E}+\mathrm{F}$ & $\begin{array}{c}\mathrm{B}+\mathrm{E}+\mathrm{F}+\mathrm{G}+ \\
\mathrm{K}+\mathrm{L}\end{array}$ & $\mathrm{G}+\mathrm{K}+\mathrm{L}$ \\
\hline Producers surplus & $\mathrm{G}+\mathrm{R}$ & $\mathrm{F}+\mathrm{G}+\mathrm{R}+\mathrm{J}+\mathrm{M}$ & $\mathrm{F}+\mathrm{J}+\mathrm{M}$ \\
\hline External benefit & $\mathrm{A}+\mathrm{H}+\mathrm{J}$ & $\mathrm{A}+\mathrm{H}+\mathrm{J}+\mathrm{M}+$ & $\mathrm{N}+\mathrm{T}$ \\
\hline $\begin{array}{l}\text { Government cost }- \\
\text { subsidies }\end{array}$ & $\mathrm{zero}$ & $\mathrm{F}+\mathrm{G}+\mathrm{J}+\mathrm{K}+\mathrm{L}$ \\
$+\mathrm{M}+\mathrm{T}$ & $\mathrm{F}+\mathrm{G}+\mathrm{J}+\mathrm{K}+\mathrm{L}+$ \\
\hline Net social welfare & $\mathrm{A}+\mathrm{B}+\mathrm{E}+$ & $\begin{array}{c}\mathrm{A}+\mathrm{B}+\mathrm{E}+\mathrm{F}+ \\
\mathrm{F}+\mathrm{G}+\mathrm{H}+ \\
\mathrm{J}+\mathrm{R}\end{array}$ & $\begin{array}{c}\mathrm{N}+\mathrm{J}+\mathrm{M}+ \\
\mathrm{N}+\mathrm{R}\end{array}$ \\
\hline
\end{tabular}




\section{Decision rules in the cost-benefit analysis}

The cost-benefit analysis is a method that is used in the case of choosing when and how a government should react in the private market in order to change consumer and producer behavior. The purpose of governmental intervention is to achieve a situation in which the marginal cost will equal the marginal benefits of this intervention. In the case of negative externalities, such an intervention often takes the form of a tax on producers, whereas in the case of positive externalities - the subsidy.

The cost-benefit analysis uses two decision rules:

1) benefits - costs $>0$ (or, alternatively, benefit/ cost $>1$ ),

2) maximizing net benefits (benefits - costs).

The first rule refers to the situation where a decision to implement a project (which has no alternative) must be chosen or rejected. When the total benefits of its implementation outweigh total costs, then it should be introduced. Such a situation rarely occurs, since there are almost always various projects which differ in type and scale. In this case, we have to reject, adopt one or several projects or implement of any at the appropriate level. What is important, the marginal costs and benefits differ depending on the scale of the project. Therefore, it would be a mistake to only compare the total costs and benefits without taking into account the marginal values. Therefore, it means that only the second rule guarantees the right decision to be made, where the marginal benefits exceed the marginal costs. This can be illustrated on Figure 3, where the horizontal axis presents the quantity of goods supplied to the market (it can also be interpreted as the projects or investments ranked in terms of cost).

Net benefits are maximized when the volume of goods at $\mathrm{Q}_{1}$ is delivered. At this point, the marginal benefit equals the marginal cost; therefore, the total benefits exceed the total costs of the highest value. At this point, the net benefit equals A (total benefits are $\mathrm{A}+\mathrm{C}$ and total cost is $\mathrm{C}$ ), which is more than in the volume of goods at $\mathrm{Q}_{2}$ where net benefit is $\mathrm{A}-\mathrm{B}(\mathrm{A}+\mathrm{C}+\mathrm{D}-\mathrm{C}-\mathrm{D}-\mathrm{B})$.

What volume of production follows the condition that net benefit $=0$ ? In the figure, it happens at the volume of $\mathrm{Q}_{2}$. This means that the average benefits equal the average costs, the total benefits equal the total costs, and the benefit/cost $=1$. Hence, the application of benefit/cost $>1$ or benefits - costs $>0$ decision-making rule leads to bad choices. From a microeconomic perspective, it means that achieving the breakeven point by the company $\left(Q_{2}\right)$ is not economically correct. Only the first criterion ensures an efficient decision. 


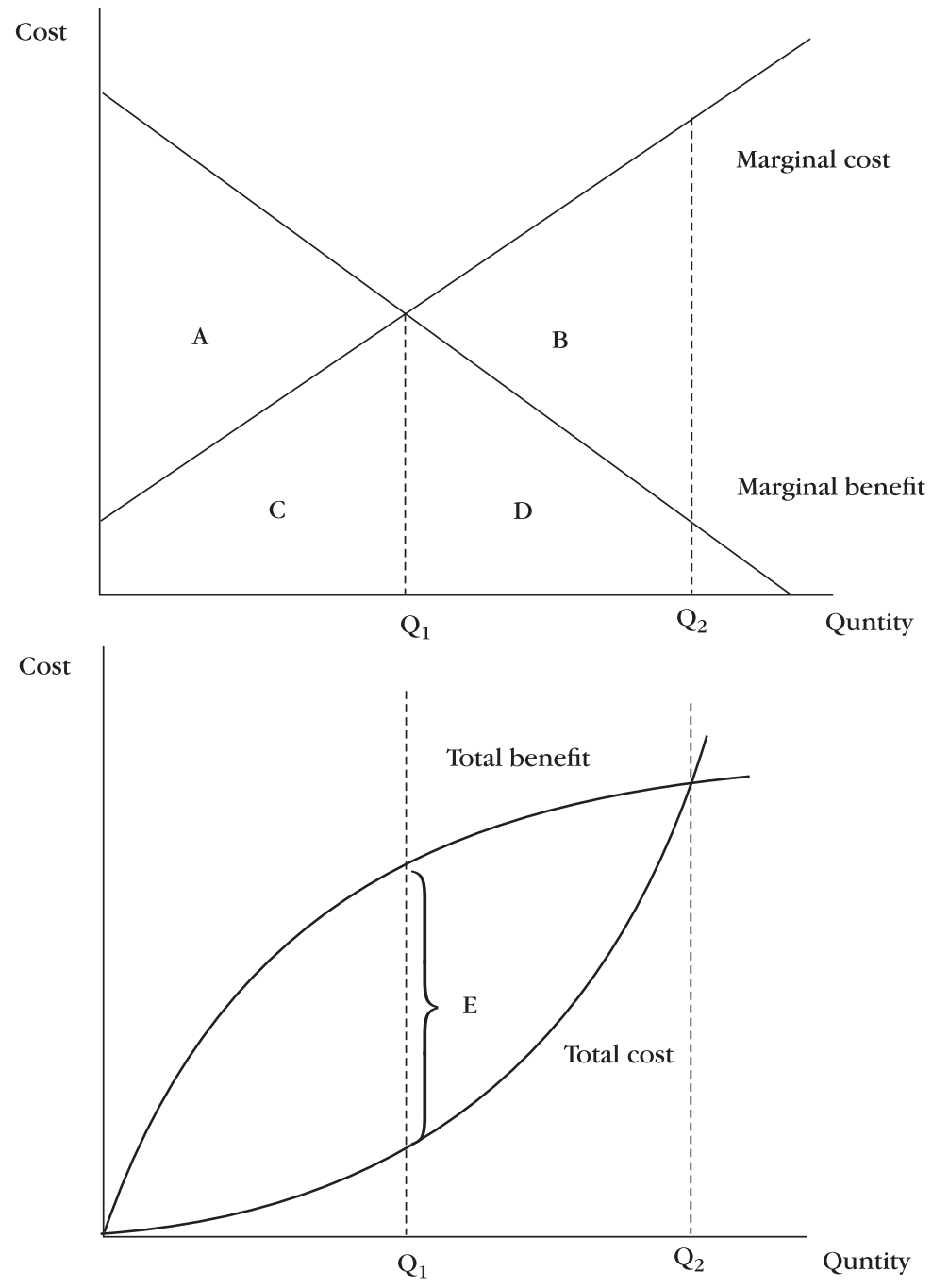

Figure 3. Decision rules

It is crucial that the decision criterion described above can be interpreted differently depending on the type of organization. For private companies, private costs and benefits matter the most. In such a case, the decision process is based on the analysis of production costs and income gained from a business activity. If the discounted profits are greater than zero, then the project is accepted. In this case, the potential externalities (costs or benefits) of its activities do not count. 
It is totally different in the case of a public institution. Here, not only private costs and benefits should be taken into account, but also social costs and benefits of the decision. It can, therefore, be assumed that the public decision-making process is based on the principle of maximizing the difference between the sum of benefits and costs, both private and social. Because the volume of external costs is, in many cases, difficult to estimate, a decision criterion is often based only on minimizing costs. In this particular case, we are dealing with the cost-effectiveness analysis, where the benefits are clearly defined (e.g., a socially-acceptable level of emissions, satisfactory level of production), whereas the costs of the projects are variable. It is necessary to emphasize that the cost-effectiveness analysis does not guarantee that a particular project, program, or policy is socially desirable. The main advantage of this approach is that we have the possibility of comparing different projects and selecting the most suitable for achieving previously-defined goals. Then, the project is selected which has the highest ratio of effects to expenditures or the lowest expenditures to effects ratio, whereas the "effects" in both cases are the same. A cost-effectiveness analysis of a project does not give a true answer to the question of whether the expenditure (associated with its implementation) is justified in the social sense. However, when the decision whether to implement a project has been taken, then this method is useful and provides the best option.

\section{Implications for the Polish energy sector}

The theoretical consequences of market failure presented above are reflected in the empirical example of the development of the Polish energy sector. The results are based on the authors' research on the long-run development of the domestic energy sector. The method of partial equilibrium analysis was used in this research, where mathematical notation and results are presented in other publications by the author(s) (Kudełko 2006, Kudełko 2008, Kudełko et al. 2011).

Different types of energy models have been developed for addressing various policy and planning concerns. The so-called "bottom-up" modeling approach is focused mainly on micro-level technological issues and does not capture important macroeconomic inter-links within the economy. These models are mainly concentrated on least-cost energy planning with reference to environmental constraints. They are limited for policy goals since they do not analyze the effects of price changes on other markets. Examples of this type of approach are MARKAL (Berger 1987), EFOM (Finon 1974), LEAP (Raskin 1986), and AIM (Morita et al. 1996).

In contrast to this type of model, the tool used here is the dynamic partial equilibrium model of the mid-term development of the Polish power sector. The model focuses on detailed issues related to energy production capabilities 
(electricity and heating markets) without capturing other macroeconomic links. It equilibrates prices and volumes of electricity and heat production, taking into account external costs related to emissions generated by energy technologies. The demand for final energy is estimated on the basis of market relations; i.e., price and income elasticity. In this representation, the buyer of energy consumes electricity and heat up to the point where his marginal willingness to pay equals the marginal cost of production. Hence, consumers maximize their discounted surpluses, and producer behavior is modeled as a profit-maximizing firm in the energy market. The markets will be in equilibrium if the activities of different "agents" are compatible. This means that the total demand for electricity and heat equals their supplies.

The basis for construction of the models is interactions between the supply and demand sides of the economy system (Fig. 4). The supply side considers possibilities of delivering fuel from domestic or foreign sources and their conversion through the energy processes. Public power plants, public CHP plants, industry CHP plants, and municipal heating plants are the main producers of energy in Poland. The variables representing these technologies include electricity and heat production and a level of technological and environmental investments. The demand side is represented by the main energy consumers; i.e., industry and construction, transport, agriculture, trade and services, individual consumers, and exports. The demand curves were estimated by appropriate price and income elasticity coefficients.

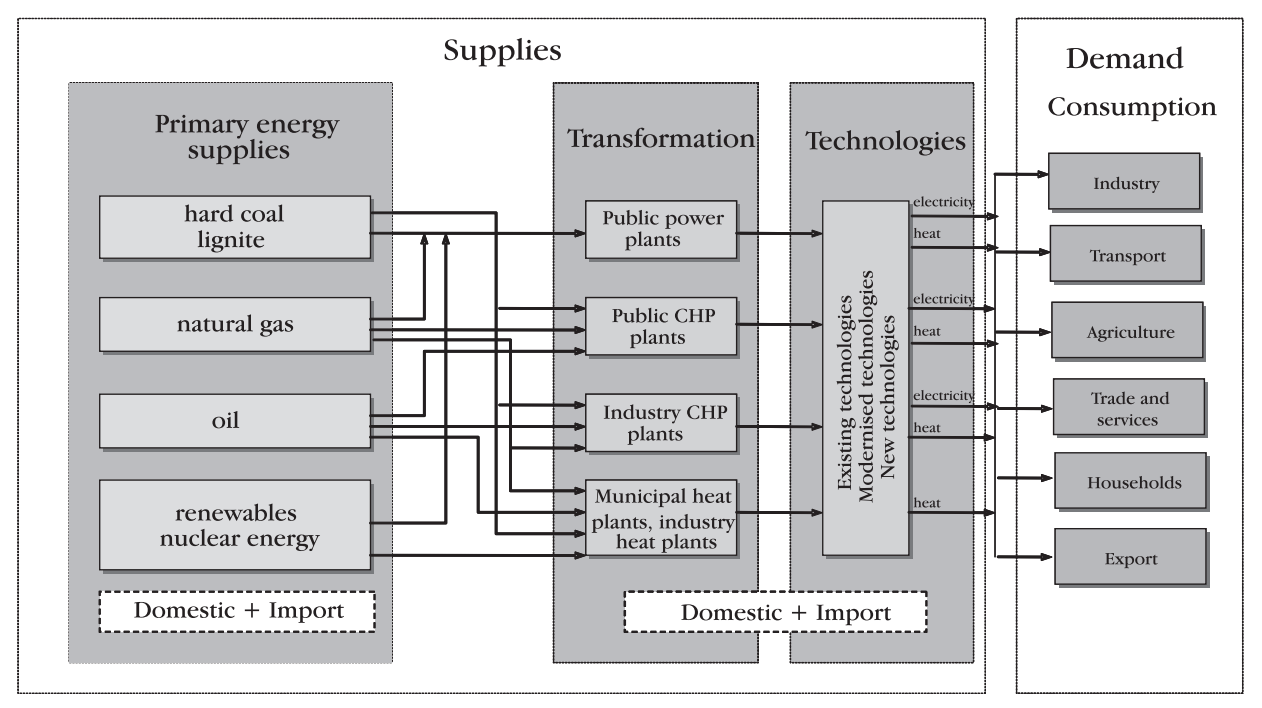

Figure 4. Structure of the model 
The results could be analyzed in the light of the two main criteria that formulate the condition of the effective allocation of resources and main scenarios of the model. The first criterion assumes a cost-effective allocation. The second criterion is based on the maximization of social welfare that is defined as a sum of producer and consumer surplus. From the social point of view, a crucial issue is the external cost caused by emission of the main air pollutants produced by the energy sector. The model has been scaled, and its results reflect the actual performance of the Polish energy sector. External costs were based on the ExternE estimations (NEEDS 2009). Therefore, the scenarios reflect the scope of external cost internalization - from its lack to its full internalization (Table 3, Option 2, Scenarios 1 and 2). Moreover, how the optimization criterion (i.e., minimizing costs (Option 1) and maximizing welfare (Option 2)) affected the cost of the sector was also studied.

Table 3 shows the results of the model calculation in respect to aggregate energy sector economic parameters in 2010-2025. In order to estimate the level of social costs and benefits, changes in consumer and producer surpluses were calculated. Consumer surplus measures the difference between how much the consumer is willing to pay and how much the price of the product is. Producer surplus measures the difference between the price that the producer receives from a supplier and the price that would be able to accept when minimizing the size of the production. Direct costs include operation costs of existing power plants as well as investment costs of building new ones. Private welfare is the sum of producer and consumer surpluses, whereas social welfare is the difference between private welfare and external costs resulting from the emission of pollutants from various energy technologies*.

Table 3

Welfare for different options of the Polish energy sector development, mln zl

\begin{tabular}{|l|c|c|c|}
\hline & \multirow{2}{*}{ Option 1 } & \multicolumn{2}{|c|}{ Option 2 } \\
\cline { 3 - 4 } & & Scenario 1 & Scenario 2 \\
\hline Discounted consumer sur plus & - & 547337 & 442142 \\
\hline Discounted producers surplus & - & 108658 & 133676 \\
\hline Discounted direct costs & 358520 & 311078 & 325171 \\
\hline Discounted external costs, including: & 265113 & 285481 & 114282 \\
\hline Private welfare & - & 655995 & 575818 \\
\hline Social welfare & - & 375396 & 466418 \\
\hline
\end{tabular}

Source: own calculations

* More on external costs estimations for domestic energy sector in Kudełko 2007, Kudełko 2009. 
Selected implications of negative externalities...

The reference is Scenario 1, where the objective function does not contain external costs. Focusing only on private production costs leads to overproduction of electricity and heat. This high level of production does not give the best result, as the producer surplus is lower than in Scenario 2 and equals $109 \mathrm{mld} \mathrm{zl}$. Nevertheless, the situation for consumers is best, and the estimated surplus reaches a value of about $547 \mathrm{mld} \mathrm{zl}$. As a result, the value of private welfare is the greatest and is about $656 \mathrm{mld} \mathrm{zl}$.

However, the maximizing private welfare criterion is not socially optimal since a high level of production and its structure (energy mix) causes the highest level of external costs, estimated at around $285 \mathrm{mld} \mathrm{zl}$. As a result, the level of social welfare is about $375 \mathrm{mld} \mathrm{zl}$. The internalization of external costs into the objective function significantly increases the level of social welfare. The amount of external costs incurred by society decreases by about $60 \%$. A reduction of electricity and heat production is the main reason for such a significant decrease of external costs, but it also causes a negative effect in the form of reduced private welfare (by $12 \%$ when compared to Scenario 1). Even though the economic situation of energy producers is improving due to the fact that demand guarantees higher energy prices and an increase in income, the situation is unfavorable for consumers. As a result, social welfare is increased by about $24 \%$ when compared to Scenario 1 . It proves that the internalization of external costs is economically justified.

An important question requiring some comments is the result of the scenario that minimizes private costs. Table 3 shows total costs of domestic energy-sector development in traditional terms of private cost minimizing (Option 1). This criterion is used in most models in which the goal is to find the right direction of energy systems development for different economic conditions, fuel potential and prices, environmental regulations, investment burdens, etc. (e.g., models MARKAL, EFOM, IPM). This approach is popular due to programming limitations for linear-programming solvers. Looking at this solution and comparing it with the results given for the differently-formulated objective function (Option 2), we can formulate the critical assessment of the development of the energy system based only on the cost-effectiveness approach (as long as we keep the technical and economic assumptions the same). In Option 2, demand for energy is variable in contrast to Option 1, where demand for energy is an exogenous parameter. Thus, in those situations where consumer response is a crucial issue (what is in fact in Option 2), the cost-effectiveness rule can give distorted results. Demand reactions depend primarily on price elasticity; in this research, it is in the range from -0.20 to -0.25 according to the demand sector. As a result, Option 1 is about $15 \%$ more expensive than the others in terms of direct costs, mainly due to higher electricity and heat production. The structure of energy production is comparable. 


\section{Conclusions}

Cost and benefit analysis is still the subject of intense debate relating to appropriate categorization and valuation of these terms. In the case of social benefits, the vaguest problems appear with identification, methods of estimation, and valuation. Both national and foreign literature clearly indicates a serious controversy in one proper definition of these terms (projects ExternE 2005, NEEDS 2009, NEWEXT 2004, Strupczewski et al. 2006). Because this issue is one of the scientific priorities implemented in developed countries, it is hoped that both research and studies will be more reliable in the future. A separate issue is the possibility of its wider use. Due to the very specific and usually unique nature of the research, the results do not always match with the characteristics of other countries. Similar problems are associated with the valuation of social costs. Disputes include the same issues as in the case of social benefits; that is, its identification and valorization. In economic analyses, some of the components of social costs (such as indirect costs) are often omitted; then, the research efforts are focused mainly on the estimation of direct costs. One of the reasons for this is the fact that a full account of social costs requires the use of appropriate methodology, usually underdeveloped. Hence, the published results of costs and benefits analysis of effective and efficient economic policies are totally different from one another. It specially applies to the type and scope of the economic intervention in the energy markets. An example of this may be climate policy, where despite international attempts, no agreement has been reached as of yet.

\section{References}

[1] Berger, C. and Haurie, A. (1987) Modelling long-range energy technology choices: the MARKAL approach, Technical Paper, Montreal: GERAD.

[2] ExternE - Externalities of Energy. Methodology 2005 Update, European Commission, 2005.

[3] Finon, D. (1974) 'Optimisation model for the French energy sector', Energy Policy, vol. 2.

[4] Kapp K.W. (1961) Społeczne koszty funkcjonowania przedsiębiorstw prywatnych, Warszawa: PWN.

[5] Kudełko, M. (2006) 'Internalisation of external costs in the Polish power generation sector: a partial equilibrium model', Energy Policy, vol. 34, issue 18 , December.

[6] Kudełko, M. (2008) 'Internalizacja kosztów zewnętrznych powodowanych przez krajowy sektor energetyczny - analiza kosztów i korzyści', Polityka Energetyczna, t. 11, zeszyt 1. 
[7] Kudełko, M. (2009) 'Metodyka szacowania kosztów zewnętrznych powodowanych przez producentów energii', Rynek Energii, nr 3(82).

[8] Kudełko, M., Suwała, W., Kamiński, J. and Kszyński, P. (2011) Modelowanie rynków energii dla różnych systemów dystrybucji uprawnień do emisji dwutlenku węgla, Studia, Rozprawy, Monografie nr 173, Kraków: Wydawnictwo IGSMiE PAN.

[9] Kudełko, M., Suwała, W. and Kamiński, J. (2007) Koszty zewnętrzne w energetyce - zastosowanie w badaniach modelowych, Studia, Rozprawy, Monografie nr 139, Kraków: Wydawnictwo IGSMiE PAN.

[10] Marshall, A. (1890) Principles of Economics, London: Macmillan.

[11] Morita, T., Kainuma, M. and Harasawa, H. (1996) A guide to the AIM/ENDUSE Model - technology selection program with linear programming, AIM Interim Paper, Tsukuba (Japan): National Institute For Environmental Studies.

[12] NEEDS, New Energy Externalities Developments for Sustainability (2009) External costs from emerging electricity generation technologies, Deliverable $\mathrm{n}^{\circ} 6.1$ - RS1a.

[13] NEWEXT - New Elements for the Assessment of External Costs from Energy Technologies, coordinator Rainer Friedrich (2004) Final Report to the European Commission, DG Research, Technological Development and Demonstration (RTD), IER, Germany, ARMINES/NSMP, France, PSI, Switzerland, Université de Paris I, France, University of Bath, United Kingdom, VITO, Belgium.

[14] Pigou, A. (1932) The Economics of Welfare, London: Macmillan.

[15] Raskin, P. (1986) LEAP: a description of the long-range energy alternatives planning system, Sweden: The Beijer Institute.

[16] Stiglitz, J.E. (2004) Ekonomia sektora publicznego, Warszawa: Wydawnictwo Naukowe PWN.

[17] Strupczewski, A. and Radović, U. (2006) 'Koszty zewnętrzne wytwarzania energii elektrycznej w Polsce', Biuletyn Miesięczny PSE Energetyka Atomowa, 7-8/06, pp. 21-32. 
